\title{
The power of place-makers and merchants: Papal and Marian items in the political economy of pilgrimage
}

\author{
Mariano P. Barbato* \\ University of Münster, Center for Religion and Modernity, Robert-Koch-Straße 29, 48149 Münster, Germany
}

Received: 8 March 2021 / Accepted: 21 July 2021

\begin{abstract}
Based on two field studies on the micro level of items which place-makers and merchants display at holy sites, an argument about the supply side of the political economy of pilgrimage is proposed. Place-makers and merchants rely on the established pilgrims' traditions but differ concerning innovations. Place-makers are the principals of the sites and invest in innovations in order to secure the site's long-term performance. Merchants rely on short-term purchase decisions of the pilgrims. They prefer tried and tested products and look for novelties which fits in the pattern of success. While the resilience of placemakers demonstrate the power of the supply side, the cautiousness of the merchants hints to its limits. Rome during Francis' Jubilee of Mercy and the Bavarian Marian shrine Altötting in the years after the resignation of Pope Benedict XVI are the case studies to illustrate these claims in the perspective of Marian and papal pilgrimage.
\end{abstract}

Keywords

Pilgrimage; Pope; Marian devotion; Jubilee of Mercy; Altötting.

\section{0 poder dos xestores dos lugares visitados e dos comerciantes: o Papa e os artigos marianos na economía política da peregrinación}

\section{Resumo}

A partir dos estudos de campo sobre o nivel micro dos artigos que os xestores dos lugares visitados e os comerciantes exhiben nos sitios sagrados, proponse un argumento sobre o lado da oferta da economía política da peregrinación. Os xestores dos lugares visitados e os comerciantes baséanse nas tradicións establecidas polos peregrinos, pero difiren no tocante ás innovacións. Os xestores de lugares visitados son os seus directores e invisten en innovacións para asegurar o rendemento do lugar a longo prazo. Os comerciantes confían nas decisións de compra a curto prazo dos peregrinos. Prefiren os produtos probados e buscan novidades que se axusten ao patrón de éxito. Mentres que a resistencia dos xestores dos lugares visitados demostra o poder do lado da oferta, a cautela dos comerciantes insinúa os límites. Roma durante o Xubileu da Misericordia de Francisco e mais o santuario mariano bávaro de Altötting nos anos posteriores á dimisión do Papa Bieito XVI son os casos de estudo para ilustrar estas afirmacións na perspectiva da peregrinación mariana e papal.

\section{Palabras clave}

Peregrinación; Papa; devoción mariana; Xubileu da Misericordia; Altötting.

JEL Codes: L83, R11, Z12.

\footnotetext{
* Corresponding author: mariano@barbato.de
} 


\section{Introduction: Looking at the supply side of place-makers and merchants}

This study on papal and Marian pilgrimage combines a micro level analysis with an discussion about power and pilgrimage on the macro level. In doing so, it follows Eade and Coleman's research agenda of a political economy of pilgrimage that demands "the detailed ethnography and the broader overview [...] that look not only at a single, seemingly isolated shrine but also at a much wider landscape of connection, communication, competition, fractal-like replication, net-working, mobility, infrastructure and governance" (Coleman \& Eade, 2018a, p. 4). It is this perspective on a "much wider landscape" of the demand side of pilgrims and the supply side of place-makers and merchants that is grasped by the term political economy of pilgrimage. These perspectives on the political economy of pilgrimage set the realms for the study's questions about the dynamics of established shrines where the original power structure of religious virtuoso, church, state, and first pilgrims has been replaced by the encounter of pilgrims with place-makers (mostly represented by the church but also by the state) and merchants. In literature the power of the demand side is stressed:

All kinds of state and church institutions try to influence, in a top-down process, the creation, recreation and destruction of pilgrim places, as well as the meaning and messages they send. Yet, pilgrims have their own policies and they are the ones that make a particular project successful or not. Through pilgrimage (migrations), permanent presence close to a site, or the financing of buildings, pilgrims create the change from the bottom up, whether this involves supporting their local church leaders or confronting them (Eade \& Katić, 2014a, p. 6).

The growing interest in merchants and markets, (Coleman \& Eade, 2018b; Reader, 2014) brings Stark's and Bainbridge's market model of religion (Stark \& Bainbridge, 1996) into consideration for pilgrim studies. Stark and Bainbridge argued that the supply side, in their argument an open market, explains much better than the focus on the demand side, faith or religious sentiments, the decline or resilience of religion in modernity.

The present study builds on these considerations and tries to contribute to these debates with two field studies. On the micro level, the article focuses on the "spectacle" (Lois González \& CastroFernández, 2020) staged through contested items of the merchandise industry (Coleman \& Eade, 2018b; Kaufman, 2005; Reader, 2014) and the place-making efforts by administrators (Davies, Howard \& Pullan, 2013; Eade \& Katić, 2014b; Kinnard, 2014; Maddrell, della Dora, Scafi \& Walton, 2018) of two sites: Papal Rome during Pope Francis' extraordinary jubilee of mercy (2015/2016) and Altötting, the most important Marian shrine in Bavaria, in the years after the Bavarian pope's resignation (field work was been conducted in 2016 and 2019). As the micro level focus on two popes already indicates, the aim of the study is to explain our understanding of the power of papal pilgrimage and its relation to other devotions on the macro level, here primarily Marian devotion, by observing the interconnectedness of place-making and items by merchants and organizers.

"[T] he triad of 'person', 'place', and 'text'" (Eade \& Sallnow, 2000, p. 9) guides the attention of the analysis. While Mary and the two popes are the key persons on the macro level, the agents studied on the micro level are the place-makers and merchants who reify Mary and popes on their items. They shape the spectacle of the places by their decisions such as the picture programs, the texts on the artefacts and the arrangement of items and temporary structures and the merchandise display. Both agents depend of the established pattern of the site and reify the persons and texts of the place. Following the rules of the market, the merchandise industry is supposed to make its decisions on the basis of short-time calculation what pilgrims want to purchase, but they also depend on the innovations that the place makers push forward. Merchants are open for promising innovations but prefer tried and tested products. Place-makers are more independent of the pilgrims' short-time decisions. Thus, they are more resilient if their innovations and investments do not pay immediately. In a short- and mid-term perspective, the place makers are more powerful than the merchants. Given 
the duration of the patterns of pilgrimage, the merchants' conservative sensitivity in respect to the taste of the pilgrims might work as an earlier warning mechanism for the place makers. However, the resilience of the place-makers can also help to keep on a strategy that will work-out in the long term. Then, the merchants will be back in business.

The study provides an ample description of two shrines based on field work and literature in order to shed some light on the relationship between place-makers and merchants on the supply side of pilgrimage.

\section{Material and methods: Rome during Francis' Jubilee and Altötting after Pope Benedict XVI's resignation}

The debate on the power of the papacy has shown the importance of pilgrim masses and the support of Marian devotion for papal power. If popes flood St. Peter's Square with pilgrims, particularly during papal audiences or the Angelus prayer, the pope can show to his global flock and to the world that the masses support him. Marian sites provide a hub for the travelling pope and, in turn, the papal traveler also supports the Marian shrines' prestige. The field work is based on these findings from previous research and debates (Barbato, 2020a, 2020b; Hermkens, Jansen \& Notermans, 2009b; Rousseau, 2016; Zimdars-Swartz, 2014).

Rome as the residence of the pope and the center of Roman Catholicism is an obvious case. A Holy Year, like the extraordinary Jubilee of Mercy, is particularly suitable to study the efforts of merchants and place-makers to attract pilgrims. Within the archipelago of Marian shrines, one with a special relationship to a pope, like the Bavarian Altötting for Pope Benedict XVI, has been selected. The years after the resignation of Pope Benedict XVI highlight the resilience of the co-constitutive support of Marian and papal pilgrimage. Rome and Altötting are, thus, considered as suitable spots on the map of papal and Marian places to conduct a micro level field analysis.

Following the interpretative turn in social science, which is based, among others, on Clifford Geertz' (1973) notion of "thick description" and, particularly important for pilgrim studies, on Victor Turner's (1995) concept of "social drama", the analysis follows a hereneutical approach. The collecting of data is done within this methodological perspective, which also explains the descriptive style concerning the presentation of the historical background, but also the presentation of the process of gathering data by the researcher, in which the presented items are contextualized. The presented data and descriptions have an illustrative purpose which are integrated in, as another qualitative scholar in pilgrim studies put it, "my experience, observations, participations, interpretations and analysis" (Katić, 2014, p. 19). The style also indicates that even quantitative controlled data is presented within the context of random observations and informal conversations that provide the thick description. Focusing on items of place-makers and merchants, the approach of "material religion" (Plate, 2015), which concentrates on material objects that are part of religious practices, is an additional important methodological perspective.

Together these approaches constitute a qualitative research agenda which expects insights for the interplay of actors by observing events, gathering items, and focusing particularly on images. Items display images and through these images they transport narratives of the ritual in which they are included, directly, as objects in the surroundings of the site or for sale at the merchants' shops from which they travel home with the pilgrims in order to spread the, sometimes conflicting, narratives of the pilgrimage. Images which are shown on items included or excluded in the rituals but also in the consumer industry of pilgrimage that supports the memory of the ritual, indicate the competing narratives and thus interests and power relations of the engaged actors, in our case, the interests and the power of the place-maker and merchants in their relations to the pilgrims. Analyzing items on display at the sites, continuously and/or during events, and for sale at the shops of the merchants around the holy site, including their cooperative and their conflictual relations, shed light on the 
relationships and the power bias within the triangle of place-makers, merchants, and pilgrims. However, a research agenda that focuses on items displayed and for sale can only describe the supply side and speculate from the decisions of place-makers and merchants about the pilgrims. More clarity in this respect would need further research on pilgrims, for instance via interviews or overviews of sold items, which is not part of the presented project and its results. The purpose of this project is more limited. It aims only at the illustration of the cooperative but also conflicting relationship of place-makers and merchants through the analysis of items through which they reify established and conflicting narratives of the pilgrimage accordingly to their notion about the long- and midterm attractiveness of the pilgrimage.

The material was gathered during intensive research stays in Rome from December 2015 to June 2016 and in October 2016 as well as during shorter visits to Altötting in September 2016 and April/May 2019. Compared to Rome, Altötting is a small place. Nevertheless, both places are dense enough to reduce the data collection to a representative minimum. The data collection in Altötting could aim to be more comprehensive in some respects. In Rome, the collection could only try to gather a small sample.

The thesis to be tested was that the supply side has to reflect the demands of the pilgrims but is free to choose their offers to them. It was also expected that Marian and papal devotions are interlinked. The focus was on items of merchants and place-makers on which they reify the texts and persons of the place.

In Rome, the extraordinary Holy Year of Mercy set the scene. During the year, a small collection of merchandise items sold in the shops around St. Peter (no Vatican shops were included) were bought in order to grasp how to reify the abstract concept of "mercy" in images on sale for pilgrims. In addition, items which reflect the Marian and papal relationships were also gathered. A specific focus was on Francis' innovative Marian icons, Mary, Untier of Knots, and Salus Populi Romani. The major Marian event in October 2016 was visited and documented by photographs of the presented Marian icons. One central observation was that the reification of mercy during the jubilee was not sought to be depicted on Marian icons but on different papal icons of Jesus. This struggle particularly illustrated telling the tensions between merchants and place-makers' interpretations and concerns towards pilgrims' demands.

To find papal traces in Altötting, the monument unveiling of Pope Benedict XVI in 2016 was attended as an example of a spectacular event for papal pilgrims at a Marian shrine. On this occasion, all merchandise shops around the center of the Marian shrine were visited and asked for remnants of souvenirs of Pope Benedict XVI. A selection of them were bought. In 2019, all items with a papal relationship displayed by the place-makers in the center of the shrine were categorized, counted and documented in order to understand the long-term perspective and resilience of place-makers.

The context of the data collection was, in addition to a literature review, formed by various interviews during these stays which provide background information or highlight certain aspects. They were not recorded but protocolled after the conversation. While quantitative aspects are considered, this is a thorough qualitative study and the generalization of the findings are bound by the limits of this approach.

\subsection{Rome during Francis' Jubilee}

John Paul II was a particularly Marian pope who brought, for instance, an icon of Mary to a permanent position overseeing St. Peter's Square from what was before a window of the Apostolic Palace. The icon is called "Mater Ecclesia" and was inaugurated during the Angelus Prayer of December, 81981 (John Paul II, 1981). The installation of the image was a sign of gratitude after the failed assassination attempt on the pope in the same year. This Marian image, closely associated with John Paul II, found its way onto the items of the merchandise industry. Figure 1 shows a magnetic sticker with this Marian icon and John Paul II. It stands for the multitude of variations in which Marian 
and papal devotion can be fused by the merchandise industry that enables "consuming vision" since Lourdes (Kaufman, 2005) on all kinds of artefacts for pilgrims.

The Mater Ecclesia example illustrates the power bias in the relationships of merchants and placemakers. First, John Paul II and his curia placed the mosaic above St. Peter's Square. Then the merchandize industry produced new items and continued to do so. 35 years later, in the jubilee year 2015/2016, the industry still produced magnetic stickers with Saint Pope John Paul II (canonized by Pope Francis in 2014) and his Marian mosaic. The place-maker had the power of the initiative. As the idea resonated with the pilgrims, the merchant continued to create and distribute versions of it.

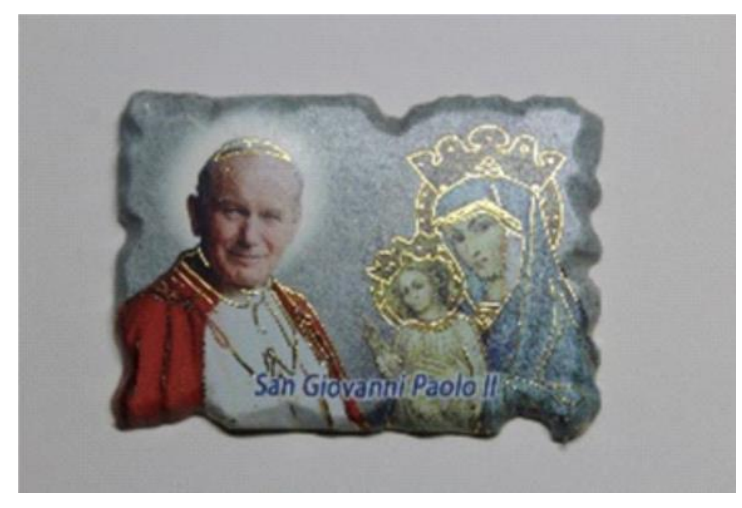

Figure 1. Magnetic sticker: John Paul II and Mary, Mater Ecclesia. Source: own elaboration.

While John Paul II was certainly a particularly Marian pope, strong Marian devotions and their promotion are not unusual for popes. One of the first acts of Pope Francis was a visit to the venerated icon Salus Populi Romani of Santa Maria Maggiore, the most important Marian shrine in Rome. The church is not far from the main station Roma Termini. As a cardinal, Bergoglio used to make a stopover at that church whenever he went to Rome. He continued this tradition as a pope, starting and concluding international journeys with a short visit to the Roman shrine. During the first lockdown of the Corona crisis, Francis made his dramatically staged pilgrimage on foot through the empty streets of Rome from Santa Maria Maggiore to the Crucifix of St. Marcello.

Concerning the image program of the pontificate, another Marian picture also made some headlines: Mary, Untier of Knots, an image from Southern Germany with a Jesuit background. This innovation of Pope Francis was so impressive that Paul Valley gave the first edition of his biography of Pope Francis the title "Untying the Knots" (Vallely, 2013). Pope Francis did no more than hang a copy of the icon in his audience room and answer questions about it. The media covered the story and, as the picture was both unknown and attractive to a wider public, it created some interest. It turned out that Francis had seen a copy during his study stay in Germany but never visited the original icon in Augsburg. The icon was venerated but had no mass appeal to pilgrims. The attractivity of the baroque painting as an icon comes with the style -baroque is after all the grandmother of all pilgrimage "kitsch"- and the message. Mary solves problems for those who come to her; she unties the knots. This story resonated and sparked interest. The merchandise industry speculated about a coming boom.

A fair, the "Fides Roma", which was advertised as the first fair on religious art on the occasion of Jubilee, offered an opportunity to inquire about the expected role of this icon. The fair presented devotional items for Catholic pilgrims by various international producers. It took place at the new convention center Fiera di Roma on the outskirts of the city from February 6 to 8, 2016. Almost three years after the beginning of the pontificate and the presentation of the image Mary, Untier of Knots in the audience room, copies of the icon found their way onto the market of merchandise items. I asked one of the producers of large wooden Madonna statues, who had, from Loretto to Lourdes, all the main 
Marian icons on display, if they were considering producing the icon from Augsburg. The exhibitor had no idea about Augsburg. For her, it was the new papal Madonna. Although the original painting as well as the papal copy is a picture not a statue, she told me that they were thinking about including an Untier of Knots statue in their program. They presume that this icon will be attractive to the consumer. It might become the next best seller on the market. During later visits at various Marian pilgrim sites, I encountered smaller items of the icon, for instance prominently displayed in a shop at Leuca, a Marian shrine in Southern Italy where St. Peter is presumed to have landed. Figure 2 shows the shop arrangement.

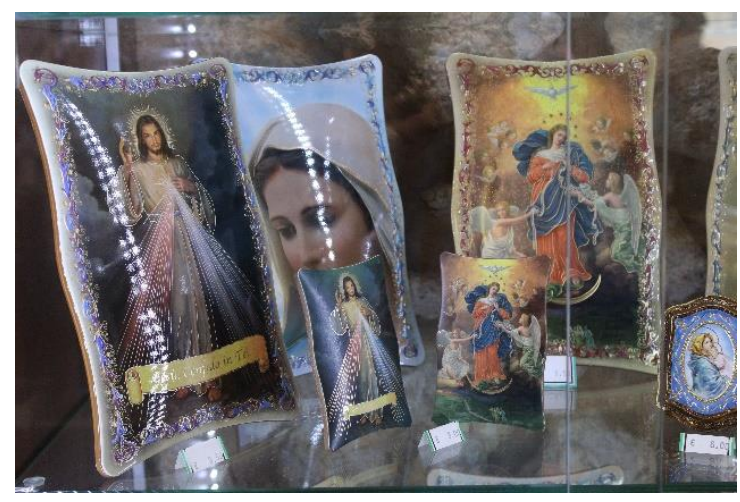

Figure 2. Mary, Untier of Knots, Shop at Leuca, Italy. Source: own elaboration.

Today, there are statues for sale on the internet, however the initial interest of the media, merchandise industry, and Marian admirers failed to reach the masses. Neither the place makers in Rome nor the ones in Augsburg did much to promote the icon. Place-makers have the initiative for innovations and the merchants are ready to follow if they expect an opportunity to increase their sales. However, they depend on the continuity of the place-makers efforts to establish a new picture program.

Noteworthy is the Marian event of the Jubilee in October 2016. It was scheduled as the great gathering of Marian shrines and devotees. Marian shrines from all over the world were invited, but also, to reduce costs and make it more inclusive, the Roman parishes of non-Italian languages presented copies of their Marian icons from home. Measured in mass presence of pilgrims, the event was less successful than a well visited papal mass. St. Peter's Square was half empty, but enough pilgrims gathered to make the event a lively celebration. While bringing Marian pilgrims to Marian shrine during a papal visit works rather well, Marian devotees seemed to be less enthusiastic about accompanying their icons to Rome and presenting them to the pope. As there was no official documentary available and the various groups could not always be attributed to one icon, no exact figures of the participation of shrines can be presented. However, it is safe to say that approximately fifty groups were presenting icons. Among them were the great shrines of Lourdes and Fatima, but also our second case, Altötting. The round was opened by the icon of Pompeii, who was already center stage during the solemn eve prayer, which was attended by a very small group of devotees. The closing role belonged to the Roman icon Mary, Salus Populi Romani from Santa Maria Maggiore, which resided during the prayer as the icon venerated by the pope. Figure 3 shows a selection of the Marian icons which were presented at the event.

Within this round of Madonnas, one was missing: Mary, Untier of Knots. Neither the Pope's administration nor the administrators of Augsburg made any efforts to promote this specific icon. At least in Rome, Mary, Salus Populi Romani was the major icon to represent the Virgin Mary, not the 
German-Argentinian newcomer. The speculations of the merchandise industry did not come true ${ }^{1}$.

(a)

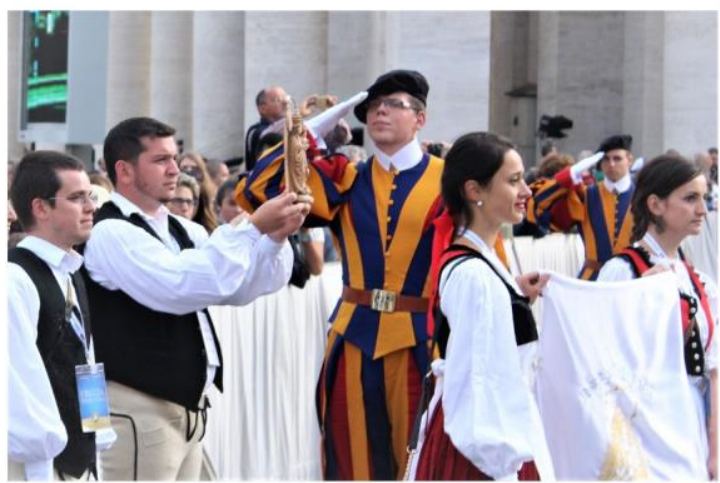

(c)

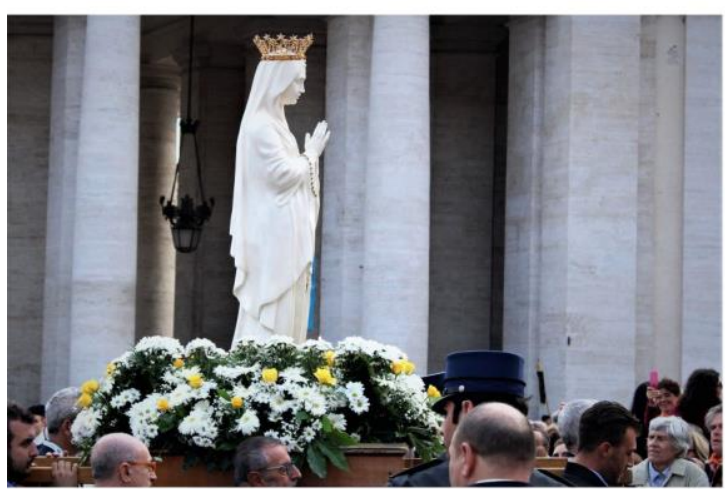

(e)

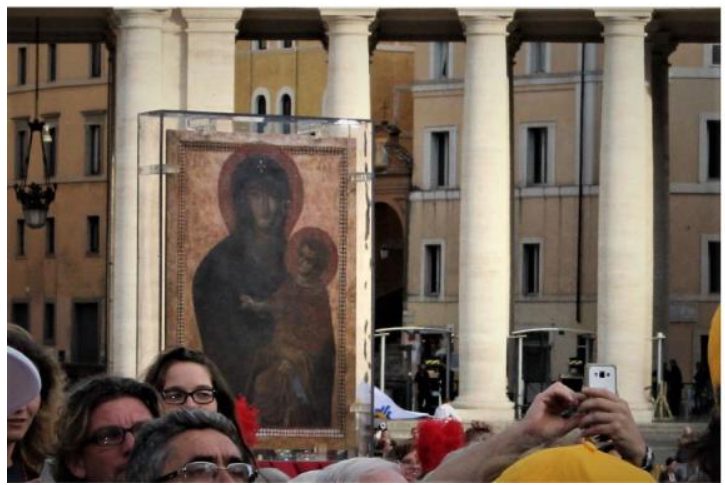

(b)

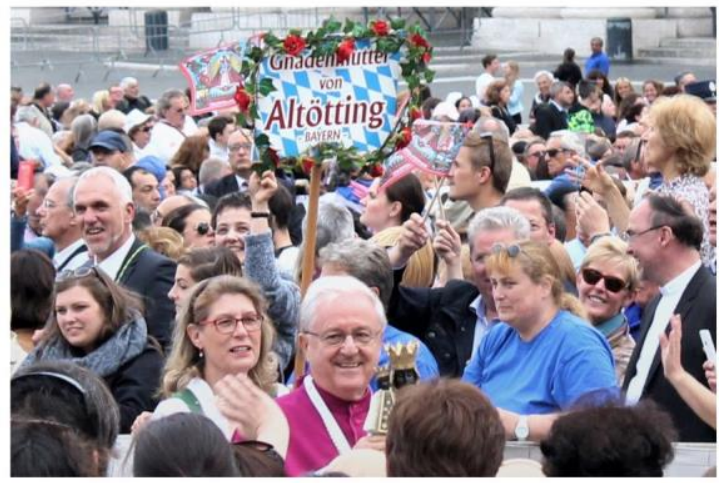

(d)

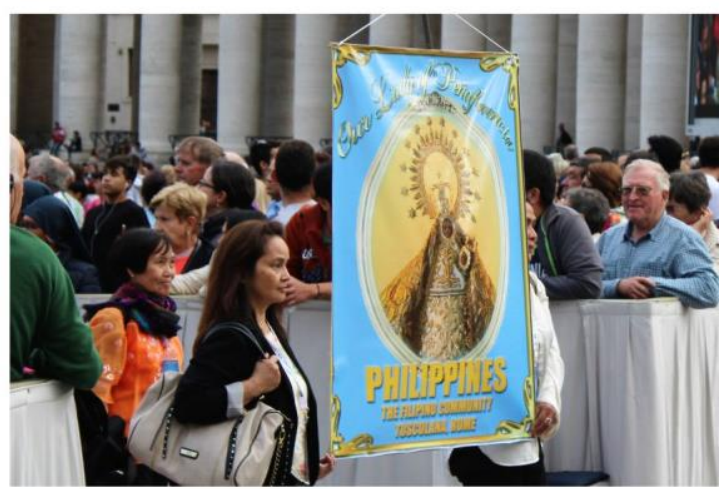

(f)

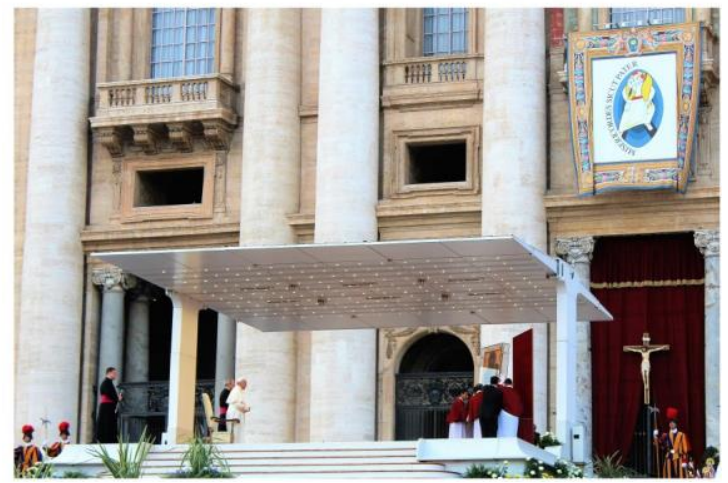

Figure 3. Marian icons at St. Peter's Square: a) Our Lady of Csíksomlyó; b) Our Lady of Altötting; c) Our Lady of Lourdes; d) Philippine Community Rome; e) Salus Populi Romani; and f) Salus Populi Romani in front of Pope Francis. Source: own elaboration.

1 In May 2021, Pope Francis initiated a global and virtual rosary to pray for the end of the pandemie. Each day a different Marian shrine of the Catholic world was leading the rosary prayer of the virtual community who joined the prayers via the internet. The final site of the last day was the Lourdes Grotto of the Vatican Gardens where Pope Francis joined the rosary. However, not Lourdes was the main icon. Finally, the Bishop of Augusburg, Betram Meier, brought the copy of Mary, Untier of Knots to Rome and to the pope. 
A second example of the Jubilee, related to an icon of Jesus Christ, might also serve to shed light on the interdependence of place-makers and merchants and their differences concerning innovations. As the extraordinary jubilee was a jubilee of mercy, the reification of the mercy of God on items was an important task for place-makers and merchants. The legacy of John Paul II provided an image, however much contested, to reify the Divine Mercy: an image of Jesus visioned by the Krakow nun Faustina Kowalska (1905-1938). In the visions of Faustina, Jesus called for repentance and also offered his mercy to the biggest sinners if they converted and entrusted their life to him. Jesus extolled several devotional practices, among them the veneration of an image of him as seen during the vision: a standing Jesus with sores and long dark hair, who looks directly at the viewers and blesses them with a gesture of his right hand. From his heart blue-white and red rays emanate symbolizing the blood and water he spread at the cross as signs of his grace and mercy for the sinners. John Paul II canonized Faustina and fulfilled the requirements of the visionary for the life of the church in the Holy Year 2000. Due to this papal support, the picture rapidly became a global icon, to the distaste of some who objected not only to the style but also its entanglement with a rather conservative form of piety and doctrinal idea of mercy, which is linked to a total conversion of the heart and less on social work.

The World Youth Day during the Holy Year took place in Krakow where John Paul II, Faustina, and the image dominated the official image program. In Rome, however, the icon was marginalized in the picture program. Only at one occasion, at the eve of its feast, Sunday after Eastern, it was allowed to play a minor role during a papal event. Instead, Jesuit artist Marko Ivan Rupnik, whose mosaics decorate such eminent places of Catholic pilgrimage like the new basilicas of Fatima, Rotondo, and the shrine of John Paul II in Krakow, was entrusted with the task of creating a logo for the Jubilee of Mercy. The Rudnik logo shows Jesus Christ as the pastor carrying a fellow human being on his shoulder, like the traditional icon of Jesus and the sheep. This image did not appeal to everyone, either. Nevertheless, the Rudnik icon was the central logo of the Holy Year and the Vatican was eager to display it in many different formats. The merchandise industry used it as well. However, Faustina's icon was another option. In contrast to the modest efforts in promoting the icon of Mary, Untier of Knots, John Paul II had successfully established this picture program for the theme of divine mercy in a sustainable way. Could Rudnik's logo or Faustina's image dominate the scene of merchandise items and thus the realm of memories of the Holy Year? Which of the two would pilgrims choose to take home with them on souvenirs? The merchandise industry opted for a broad variation: the logo, the icon, or both. Figure 4 shows a selection of magnetic stickers which represents these solutions to reify God's mercy in the year of the papal jubilee.

(a)

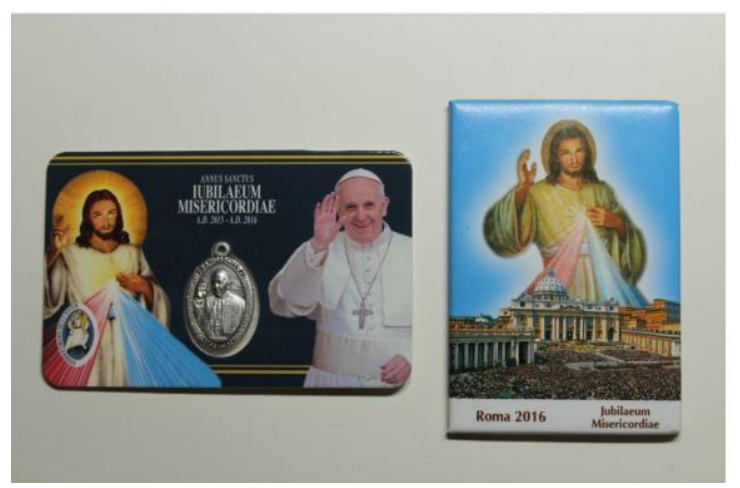

(b)

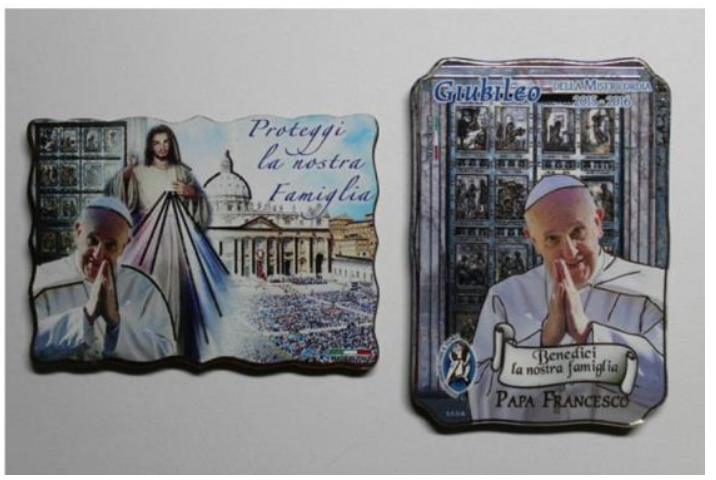

Figure 4. Representing Mercy in the Jubilee Year: a) a plastic card with a medal showing the logo and the icon, and a magnetic sticker showing the icon above St. Peter's Square and pilgrim masses; and b) two magnetic stickers by the same producer, one showing the icon, the other the logo. Source: own elaboration. 


\subsection{Altötting after Benedict XVI resignation}

When Benedict XVI resigned, the papal decision was nothing but a catastrophe for Altötting. The investments in becoming a permanent hub for a fusion of papal and Marian devotions suffered a major setback. However, the efforts of the place-makers continued, hoping for a long-term effect of a dense landscape of Marian and papal devotion.

Altötting is a place with a long history. The octagonal structure of the Chapel of Grace (Gnadenkapelle) goes back to the $8^{\text {th }}$ century. The Frankish king Carloman established his royal court and a monastery there in the 9th century. The continuity of the legacy in stone survived only in the foundational walls of the chapel as the whole town was devastated in 907 by Hungarian raiders. It took until the $15^{\text {th }}$ century for the place to flourish again as a pilgrimage site. Healing miracles established the site as a Marian pilgrimage that soon became a regional center and the main Bavarian shrine. The hearts of the Bavarian dukes and kings were buried in the chapel, supporting the claim that Altötting and its Marian devotion is the heart of Bavaria. Despite shrinking numbers of pilgrims, it is still the most important Bavarian and the largest German pilgrimage site. In 1996, the mayors of Altötting and Loreto were the initiators of the Shrines of Europe network that today includes Czestochowa, Lourdes, Fatima, Mariazell, and Einsiedeln and constitutes a platform for the cooperation for religious tourism in the seven most important European Marian pilgrim shrines (Willmerdinger \& Stummer, 2008).

Altötting attracted three papal visits: Pius VI (1782), John Paul II (1980) and Benedict XVI (2006). The exchange of prestige was mutually beneficial, at least for the last two papal trips, the successful exchange was engraved in the landscape of the site while the first visit was lost in memory. While the sanctuary worked as a Marian hub for brining pilgrims to the popes, the pilgrim popes in turn supported the Marian pilgrimage to the site. How highly local place-makers value the papal impact on their shrine can be illustrated by a survey sample of papal traces in the holy districts that are more or less deliberately staged by the place-makers - mainly the episcopal administration and the Capuchin Franciscans, but also others like the Marian Congregation, a lay fraternity, and supported by the town municipality.

A survey about the papal impact on pilgrims has to be concentrated on the parts of the town where all pilgrims usually flock. What can be called its holy district is covered by two squares and the surrounding buildings, the place of the chapel (Kapellplatz) where the venerated sculpture has its home in the Chapel of Grace (Gnadenkapelle), and the Conrad of Parzham Square (Bruder-KonradPlatz) in which the large, neo-baroque St. Ann Basilica is located. During feast days, the Marian icon, a small $13^{\text {th }}$ or $14^{\text {th }}$ century statue made of lime wood, is carried in a procession from the chapel to the basilica in order to have the statue among the pilgrims when mass is celebrated. Along the way, the procession passes the Capuchin monastery where the second patron of Altötting, Conrad of Parzham O.F.M. (1818-1849), worked and now has his shrine ${ }^{2}$. The restaurants, hotels, and shops are situated around this district. The century old Stiftskirche, now the parish church, which is also used for those pilgrim events which are too big for the chapel but not large enough for the basilica, the episcopal administration of the site, the town hall, the museum, which is named after Pope Benedict XVII, and an adoration chapel are located around the Kapellplatz. At the other end of the Kapellplatz, seen from the way to St. Anna, stand two churches: the former Jesuit Church devoted to Mary Magdalena, now also under the guidance of the Capuchin Franciscan, which harbor an image of St. Jude. As a third venerated icon. In the Church of the Marian Congregation, the beatified Jesuit Father Rupert Mayer (1876-1945), head of the congregation, is commemorated, although his resting place is in Munich. This church has two larger than life statues of two popes on its outer wall, greeting the pilgrim at the Kapellplatz: John Paul II and Benedict XVI.

2 When I visited for the sake of another project the Capuchin Franciscan Church of Philadelphia, the frater who shook my hand told me that the first friars who founded church and monastery of Philadelphia shook Conrad's hand when they left for America as he did now with mine. 
These two churches with the icons inside and outside their walls marked the starting point for a little walk to the St. Ann Basilica in order to count how often popes appear on the ways of the pilgrims. It is estimated that the route is roughly 500 meters long. The selected day was May $1{ }^{\text {st }} 2019$, which is one of the prominent feast days of the shrine, as Mary is also venerated as Patrona Bavariae, the patron saint of the Bavarian nation ${ }^{3}$. A concrete day was also chosen to count those items which are temporarily on display.

Next to the church of the Marian congregation, a small square, in fact, rather a passage, is named after Pope Benedict XVI. It appears the buildings around the small square, including the Church, were competing for having the street sign on its wall. Obviously, the compromise was to allow each of the three buildings its own sign. This anecdote might shed a qualitative light on the debate about who benefits from the pope, for a quantitative survey it might disturb the sample. For that reason, the square was excluded.

Also excluded was the museum, while the interiors of the churches are included. The museum, located in the House Pope Benedict XVI (Haus Papst Benedikt XVI) harbors a tour through the history of the pilgrimage and includes the treasures of the site. The museum opened in 2009 after the bishop decided to turn the room of the old treasury into a chapel of perpetual eucharistic adoration. However, the new expansive location, with a certain architecture that blends an old building looking out onto the Kapellplatz and a modern annex at its back, was not just a replacement solution. It was meant to embrace pilgrim masses attracted not only by the traditional pilgrim goals but by the Bavarian pope, and the new name marks this intention. After Pope Benedict XVI's resignation, it looks, at least so far, as if this did not work out. Time will tell, but currently neither the Bavarian pope nor the prestigious new site are magnets for visitors. The rationale behind the exclusion of the museum is that the visit there is a deliberate decision of the pilgrims to encounter pilgrim and papal history. In contrast, encountering papal traces on the ways between shops and churches has not necessarily something to do with a choice of the pilgrims to reflect on the papal legacy on the shrine but with the efforts of the place-makers to show a fusion of Marian and papal devotion in Altötting's pilgrimage landscape. Also, the numerous papal items on this display at the shops were excluded. As in Rome, Benedict XVI has mainly disappeared. There is only one pope for sale, as in Altötting. Nevertheless, the shopkeepers are happy to show relics from the past upon request, which some still stored, at least, in 2016. Figure 5 shows a sticker of the Bavarian pope taken from storage upon my request. The then still filled storage of mass production shows the devaluated merchandise items after Benedicts' XVI resignation, waiting for a revival.

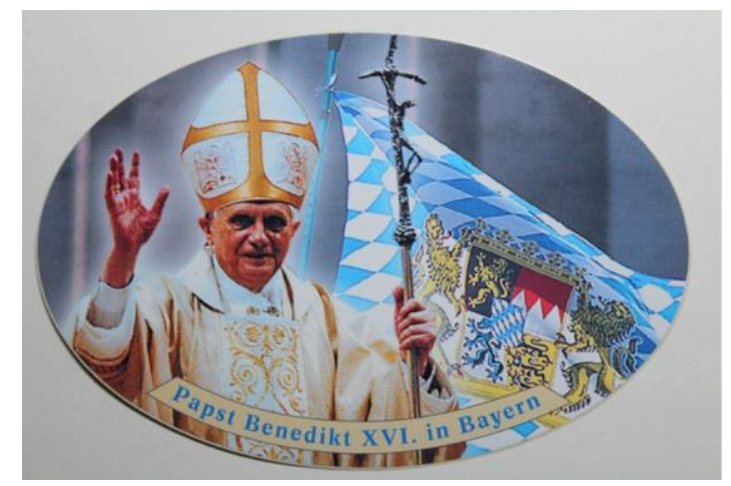

Figure 5. Pope Benedict XVI in Bavaria sticker. Source: own elaboration.

\footnotetext{
${ }^{3}$ At the request of the last Bavarian king, Pope Benedict XV officially granted that patronage in 1917. The anniversary in 2017 was celebrated in a speedily secularizing Bavaria along with several pilgrim events all over the country's dioceses already years before.
} 
While the merchants might have had to calculate their losses after the resignation of Benedict XVI, the place-makers continue their efforts to establish a papal pilgrimage landscape at their Marian shrine, which only makes sense as an investment in the future and with an anticipated return of the attractiveness of the papacy in general and especially the Bavarian pope. While the benefits are mutual, the idea to support Catholic identity as devotional to the pope might rank only second after the expectation that the papal shine will support the prestige of the local shrine.

An example of the resilience of the place-makers is the erection of a statue of Pope Benedict after his resignation. On September 11, 2016, 10 years after Benedict XVI's visit to Altötting, the monument was unveiled in a ceremony. Bishop Georg Gänswein, the private secretary of Pope Benedict XVI, was the guest of honor. Somehow not just the statue but also the secretary represented the pope emeritus on that day in Altötting. The first two panels of Figure 6 show the unveiling of the statue and the blessing Gänswein amidst the pilgrim masses in St. Ann. The second two panels give an impression of the pilgrim masses during the respective event, first at the Mass, then at the ceremony. While the unveiling was attended by few pilgrims, the mass celebrated by Gänswein saw a packed St. Ann Basilica. The investment of a landscape that is densely inhabited with papal images is not successful enough to attract pilgrims as such, but the place-makers seem to intend a more indirect effect. The papal surroundings are meant to reassure the pilgrims that they are doing the ritual at the right place. The pilgrims are not supposed to applaud each new item, but the place-makers' continued investments show their trust in a well-established interconnectedness of Marian and papal pilgrimage.

(a)

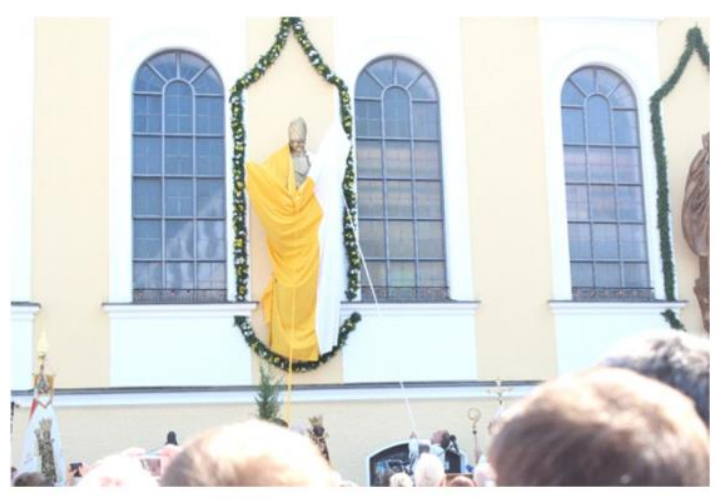

(c)

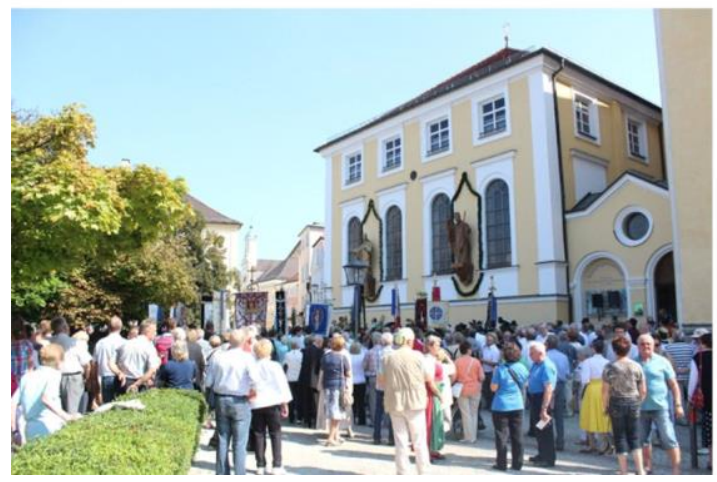

(b)

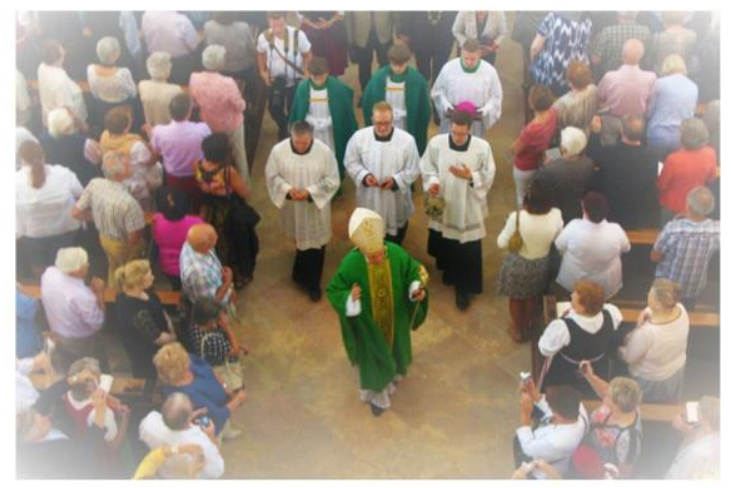

(d)

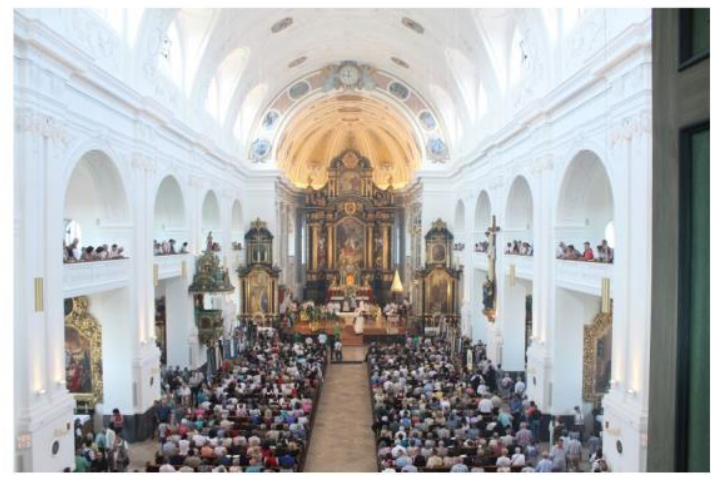

Figure 6. Representing Pope Benedict XVI and pilgrims' interest: a) Unveiling of statue; b) Blessing Monsignor Gänswein amidst pilgrims, c) pilgrims at the unveiling; and d) pilgrims at St. Ann during Mass. Source: own elaboration. 


\section{Results: Contesting Supply}

Place-makers and merchants have to develop the programs of the site. For that task, they depend on the established patterns, in our case the Marian and papal ties which they reify on their items. The reification is not static. Place makers and merchants must calculate their investments on the expectations of future returns. They must strike the delicate balance between innovation and continuity in order to please the pilgrims. Particularly, place-makers must decide on this balance and take the lead in investments and innovations. Merchants depend on these innovations and are interested in them as they calculate the impact of these impulses on the pilgrims. However, the merchants depend much more on the short-term effect of the pilgrims' decisions to buy a product and are thus more careful to stick with the tried and tested products. On the other hand, they have to abandon the reifying process of a program that does not pay. As the principals of the site, the placemakers are more independent of the short-term decisions and have the resilience to cope with shorttime bad investments that might pay in the long term. The place-makers have to establish coherent image programs which the merchant can then support with their products. However, despite contestations and some incoherence of the place-makers, as soon as one image program has been successfully established, the merchants can work with multiple options. If the agenda is not comprehensive and coherent but shows ruptures or even contestation, the merchants but also local place-makers have to write off their investments. Place makers' resilience is an asset if they bet on long-term gains, it can become a burden, if place-makers insist on innovations that do not work.

These results have been drawn from the cases of Rome during Pope Francis' Jubilee of Mercy and of Altötting after the resignation of the Bavarian Pope Benedict XVI. In both cases items and their images displayed by place-makers as part of events and/or the continuous decoration of the sites and by merchants in order to offer them for sale are observed, collected, enlisted, counted, photographed, analyzed, and presented. Backed by the debates of the literature as well as by background interviews and informal conversations, the items and their images explain the long-standing narratives and the tried and tested products, but also the innovations, successful and failing ones, of the pilgrimage. Through this prism of the cooperative and conflicting display of items, the power relation of the supply side between place-maker and merchants can be illustrated and analyzed. The items tell how placemakers suggest or push innovations and how merchants integrate these innovations into their business calculations and their preference for tried and tested products. This allows a limited speculation about what they consider the interests of the pilgrims to be.

\subsection{Rome and the Jubilee}

The case of Francis' Jubilee shows that the merchants were ready to promote whatever placemakers suggested and pilgrims might buy. When Francis hung up a new Marian icon in his audience room or when Rudnik was chosen to create the official logo for the extraordinary jubilee of Mercy in 2015/2016, the merchants observed these moves and made their choices based on their expectations of how the pilgrims would react to the ideas of the place-makers. When the papal place-maker had no intention to push a new icon deliberately but followed the pattern of an established icon, like Mary, Salus Populi Romani in the case of the Marian event of the Jubilee, instead of promoting a newcomer, Mary, Untier of Knots, the expectations of the merchants evaporated. While media and merchants were ready to promote the new icon, the papal place-maker preferred to concentrate on an already established one, Mary, Salus Populi Romani. The pilgrims' chances of becoming aware of the new icon, not to speak about considering a pilgrimage to Augsburg or of relating the devotion of Mary, Untier of Knots to papal identity construction, failed.

However, neither is ieasy for the place-makers to get new agendas pushed through against established ones. When Rudnik's logo was chosen for the Jubilee instead of using the Faustina icon established by John Paul II, the logo became important for the merchandise industry. However, their 
expectations that this logo would trump over the old image program and meet the taste of the masses were low. Thus, industry and merchants opted for variations and included the established icon together with the logo in the image program of their merchandise items. While the Marian devotees might be happy with a pluralistic representation of Marian shrines and also accept the dominance of the local shrine in Rome, the issue becomes trickier in the reifying of divine mercy. It is here, where the two universes of papal pilgrimage, the conservative and the liberal clash: Rudnik or Faustina, the one more in the tradition of the corporal works of mercy, the other more in line with the spiritual works of mercy. The merchants had the task of bridging that rift.

\subsection{Altötting after Benedict XVI's resignation}

When Benedict XVI resigned, his merchandise items largely gave way to those featuring Francis. However, while there is just one sitting pope in the Catholic universe, the already dense papal landscape of Altötting grows. This landscape shows how dense the ties between papal and Marian pilgrimages are and how resilient place-makes are to change their long-standing strategies.

Despite the many exclusions mentioned above and the limited space of two squares and six churches linked by a tour of approximately 500 meters, 61 papal traces more or less deliberately staged by the place-makers to enrich the spectacle of the site can be found. These traces can be divided into four categories: inscriptions, including quotes from the popes; images, like Leo XIII at the altarpiece of St. Ann, a painting of the beatification of Father Rupert Mayer that includes John Paul II, or a photo of Benedict XVI in the chapel; papal coat of arms, marking some spots but also gathered into an installation at the entrance of St. Ann; other artefacts and monuments (big and small), including the two larger than life statues as well as a sign post for the Pope Benedict Walk; and items temporarily on display, like leaflets. Table 1 shows the gathered data.

Table 1. Papal traces in Altötting

\begin{tabular}{lc}
\hline Papal images & 21 \\
Papal coats of arms & 16 \\
Papal artefacts and monuments & 10 \\
Papal quotes and inscriptions & 7 \\
Temporarily displayed items & 7 \\
In sum & 61 \\
\hline
\end{tabular}

Note: Collected in May, 1, 2019. Source: own elaboration.

The unveiling of a Benedict XVI monument was just one further investment. At the moment, these investments do not pay. In particular, the museum that meets the standards of high culture of modernity does not attract the expected masses. While the whole Kapellplatz was packed during the visit of Pope Benedict XVI and the busses brought pilgrims to the meadow outside the town in order to watch the event at Kapellplatz and St. Ann on large screens, the museum is rarely visited and even the anniversary ceremony saw a packed St. Ann Basilica but only a modest interest in the unveiling of the monument.

Nevertheless, only some of the 61 papal traces counted in the center of the site were leaflets. Most of the traces grew in the time span of over a century. Local place-makers are, just as merchants, exposed to the decisions of the pope, if they rely on papal prestige. Obviously, the bets of the placemakers are still on the well-established interconnectedness of Marian shrines and papal devotion. They trust that their resilience will work out in the long rterrm and that the legacy of the Bavarian pope will play an important role again. If this place-makers' expectation comes true, the merchants will follow suit. 


\section{Discussing persons, items, places and spectacles}

Ian Reader rightly stressed the importance of the market for a pilgrimage site to flourish:

Market engagement [...] is an essential characteristic of pilgrimage, without which the pilgrimage places and routes that are famed and successful around the world, would not have attained the status and preeminence that they have and would not be able to maintain them (Reader, 2014, p. 15).

As Reader knows, the political economy of pilgrimage does not confront us with a market in tune with a neoliberal model. The impact on institutional decisions of non-market actors is very high. They have their own agency as place-makers to construct the landscape of the spectacle. Indeed, to answer the question which "circumstances and phenomena [...] make pilgrimage successful or not" (Reader, 2014, p. 19), the items and spectacles offered for sale or for free at the places of the pilgrimage "stock exchange of the religious economy" (Eade \& Sallnow, 2000, p. 24) are crucial.

The findings of the micro studies stress that place-makers have more room to maneuver than merchants. Both work within the established patterns, in our case the importance of the ties between papal and Marian devotion. Their task is to reify these persons and text on the items of the place. Place-makers, can suppose innovations and make the decisions to push them through or just let them develop without much support. Merchants are open to new ideas, but they need the support of the place-makers to establish them. In case of doubt, they stick to tried and tested products and abandon picture programs if they do not pay, even though they keep remnants in stock just in case. The resilience of the place-maker and the flexibility of the merchants can work together if the placemakers invest in long-term gains, and the flexibility of the merchants helps to distinguish sustainable and less prosperous innovations.

These findings concerning the supply side might aid the debate about the relations of the political economy. A pilgrimage counts as successful in these debates if the place-makers and merchants can create a space to build, to use Turner's term, a strong "communitias". Like in the classical structuralist accounts, the elite must engage successfully with the masses. However, the place-makers are not able to impose their script on them. The supply side and its interplay of place-makers and merchants have to develop an attractive and sustainable offer.

The well-established interconnectedness of Marian shrines and papal devotions is, despite an observable decline, still working. At least, place-makers and merchants continue to reify these ties on their items. It needs further research to make good on these claims. However, I would argue that in contrast to the purist critique of the marketplace as opposed to the sacred experience, that the merchandise items and spectacles of the place-makers contribute crucially to the success of the exchanges. Kaufmann's insights (Kaufman, 2005) on the creation of a consumer culture in Lourdes cannot be over-estimated. This consumer culture of the merchandise industry and the spectacles of the place-makers were essential to create what it means to do a Catholic pilgrimage in modern times. Turner's classical argument about the creation of "communitas" (Turner, 1995; Turner \& Turner, 2011) through a ritual, however contested it might be, is still the motor of the relationship between institutional elites and pilgrim masses (Anderson, 2016, p. 54), and that motor drives the power of pilgrimage. The spectacle of places and items, their representation of texts through image programs, can, however, support or ruin the ritual as a crucial intervening variable. The style invented by the merchants, builders, and administrators of Lourdes (Kaufman, 2005) still has its contenders but no other style has provided better fuel for the engine so far.

"The change in architectural design raises questions about aesthetic appearance. Are the new structures sympathetic to their surroundings? What values are being employed when we describe them as 'kitsch' or 'overbearing'?" (Eade \& Katić, 2014a, p. 10). From the papal perspective of placemakers, Paul VI pointed out the importance of a style that is in line with the established pattern. In his address to the Mariological Congress that also convened the representatives of Marian shrines during 
the Holy Year 1975 in Rome, he stressed the importance of a second way, other than theology and doctrine, to Marian devotion: beauty, the via pulchritudinis. According to Paul VI, this second way is particulary suitable for what he called simple people (Paul VI, 1975). In other words, beauty is defined by the pious taste of the masses. While some place-makers in charge of Marian sites, like Wilhelm Imkamp, were ready to work on this basis and defend the kitsch (Imkamp, 2014), others were keen on meeting the cultural standards of time and tradition. The global success of Rupnik among placemakers reveals the desire for a difficult compromise. The merchant and the market have a good sensor for what pilgrims like and what they do not. They were ready to push the new papal icon Mary, Untier of Knots while the papal place-maker preferred the established icon of Mary, Salus Populi Romani. When the administration of the Jubilee pushed Rudnik's logo, the merchants followed reluctantly and preferred to keep with the safe bet on Faustina's image of the Divine Mercy.

What some see as kitsch might be helpful for the religious experience of others. Therefore, Reader's argument that the religious experience also depends on the market is as valid as Eade's and Coleman's remark that a previous "fetishization of the power of the sacred must not be replaced by the fetishization of the transcendental forces of the market" (Coleman \& Eade, 2018a, p. 7). My bet would be on the constitutive role of the place-makers to perform the "communitas" of pilgrims and institutional elites while the merchants play a crucial, intervening role, which might reflect the needs and tastes of the pilgrims better than the high cultural wishes of some place-makers.

\section{Conclusions: Place-makers innovate while merchants follow sometimes}

The results of the field studies in Rome in the Year of the Extraordinary Jubilee of Mercy and in Altötting in the years after Benedict XVI's resignation illustrate the relationship of place-makers and merchants on the supply side of the political economy of pilgrimage. The study of the micro level analysis shows that the macro pattern of Marian and papal ties is still reified on the items which place-makers and merchants display on their sites. The social drama of the ritual of pilgrimage takes place in a space decorated by the supply side of the political economy of pilgrimage. Place-makers and merchants seem to calculate that the established macro patterns of Marian devotion and papal pilgrimages still attract the pilgrims and will thus pay-off on their site also in the long term.

While merchants must look at short-time profits, place-makers must invest in long-term gains. They are the principals of the site. They decide if they innovate or if they stick to their investments. Merchants depend on these decisions. Novelties are good for business but if the place-makers change their agendas too suddenly, this might cause problems for the merchants. In contested cases, merchants prefer tried and test products. Their sensitivity for the pilgrim's taste is much more developed than the place-makers' who depend more indirectly on the pilgrims' demand. For that reason, the more powerful place-makers would do well to watch out for the merchants' sensibilities who sometimes offer a bridge over rifts.

\section{References}

Anderson, B. (2016). Imagined communities: Reflections on the origin and spread of nationalism. (2 ${ }^{\text {nd }}$ revised edition). London, UK/New York, NY: Verso.

Barbato, M. P. (2020a). Geopolitics of Papal Traveling: (Re)constructing a catholic landscape in Europe. Religions, 11(10), 525. DOI: https://doi.org/10.3390/rel11100525

Barbato, M. P. (2020b). The holy see, public spheres and postsecular transformations of international relations. An introduction. In M. P. Barbato (Ed.), The Pope, the public, and international relations postsecular transformations (pp. 1-22). Chamm, Switzerland: Palgrave Macmillan. DOI: https://doi.org/10.1007/978-3-030-46107-2_1

Coleman, S., \& Eade, J. (2018a). Pilgrimage and political economy: Introduction to a research agenda. In S. Coleman \& J. Eade (Eds.), Pilgrimage and political economy: Translating the sacred (pp. 1-20). New York, NY: Berghahn Books. 
Coleman, S., \& Eade, J. (Eds.). (2018b). Pilgrimage and political economy: Translating the sacred. New York, NY: Berghahn Books. DOI: https://doi.org/10.1080/09637494.2021.1892993

Davies, P., Howard, D., \& Pullan, W. (Eds.). (2013). Architecture and pilgrimage, 1000-1500: Southern Europe and Beyond. Burlington, VT: Ashgate.

Eade, J., \& Katić, M. (2014a). Introduction: Crossing the border. In J. Eade \& M. Katić (Eds.), Pilgrimage, politics and place-making in Eastern Europe: Crossing the borders. Farnham, UK/Burlington, VT: Ashgate.

Eade, J., \& Katić, M. (Eds.). (2014b). Pilgrimage, politics and place-making in Eastern Europe: Crossing the borders. Farnham, UK/Burlington, VT: Ashgate.

Eade, J., Sallnow, M. J. (2000). Introduction. In J. Eade \& M. J. Sallnow (Eds.), Contesting the sacret: The anthropology of pilgrimage (pp. 1-29). Urbana and Chicago, IL: University of Illinois Press.

Geertz, C. (1973). The interpretations of cultures. New York, NY: Basic Books.

Hermkens, A.-K., Jansen, W., \& Notermans, C. (2009a). Introduction: The power of Marian pilgrimage. In A.-K. Hermkens, W. Jansen \& C. Notermans (Eds.), Moved by Mary: The power of pilgrimage in the modern world (pp. 1-13). Farnham, UK/Burlington, VT: Ashgate.

Hermkens, A.-K., Jansen, W., \& Notermans, C. (Eds.). (2009b). Moved by Mary: The power of pilgrimage in the modern world (pp. 1-13). Farnham, UK/Burlington, VT: Ashgate.

Imkamp, W. (2014). Pastorale Devotionsästhetik. Pilgern Auf Der via Pulchritudinis. In G. Riedl, H. Heinrich \& B. Meier (Eds.), Neue Evangelisierung - Kirche konkret (pp. 82-107). Paderborn, Germany: Verlag Ferdinand Schöningh.

John Paul II. (1981). Angelus. Solennità dell'Immacolata. 8 dicembre 1981. Giovanni Paolo II. Retrieved from: https://www.vatican.va/content/john-paul-ii/it/angelus/1981/documents/hf jp-ii ang_19811208.html

Katić, M. (2014). From the chapel on the hill to national shrine: Creating a pilgrimage 'home' for Bosnian Croats. In J. Eade \& M. Katić (Eds.), Pilgrimage, politics and place-making in Eastern Europe: Crossing the borders (pp. 15-36). Farnham, Uk/Burlington, VT: Ashgate.

Kaufman, S. K. (2005). Consuming visions: Mass culture and the Lourdes shrine. Ithaca, NY: Cornell University Press. DOI: https://doi.org/10.7591/9781501727351

Kinnard, J. N. (2014). Places in motion: The fluid identities of temples, images, and pilgrims. New York, NY: Oxford University Press. DOI: https://doi.org/10.1093/acprof:oso/9780199359653.003.0001

Lois González, R. C., \& Castro-Fernández, B. (2020). Spectacle and power: Sites and spaces of Papal visits. In M. Barbato (Ed.), The Pope, the public, and international relations: Postsecular transformations (pp. 133-150). Cham, Switzerland: Palgrave Macmillan. DOI: https://doi.org/10.1007/978-3-030-46107-2

Maddrell, A., della Dora, V., Scafi, A., \& Walton, H. (2018). Christian pilgrimage, landscape and heritage: Journeying to the sacred. New York, NY: Routledge. DOI: https://doi.org/10.1080/14616688.2020.1740937

Paul VI. (1975). Discorso di Paolo VI ai Congressi Mariologico e Mariano, venerdi, 16 maggio 1975. Retrieved from: https://www.vatican.va/content/paul-vi/it/speeches/1975/documents/hf p-vi spe 19750516 congressomariologico.html

Plate, S. B. (Ed.). (2015). Key terms in material religion. New York, NY: Bloomsbury Academic.

Reader, I. (2014). Pilgrimage in the marketplace. New York, NY: Routledge.

Rousseau, K. (2016). Pilgrimage, spatial interaction, and the memory at three Marian sites. Denver, CO: University of Denver.

Stark, R., \& Bainbridge, W. S. (1996). A theory of religion. New Brunswick, NJ: Rutgers University Press.

Turner, V. W. (1995). The ritual process: Structure and anti-structure. New York, NY: Aldine de Gruyter.

Turner, V. W., Turner, E. L. B. (2011). Image and pilgrimage in christian culture. New York, NY: Columbia University Press.

Vallely, P. (Ed.). (2013). Pope Francis: Untying the knots. London, UK: Bloomsbury Academic.

Willmerdinger, G., \& Stummer, J. (2008). Shrines of Europe die Marienheiligtümer Europas; [Altötting Tschenstochau - Fatima - Loreto - Lourdes - Mariazell]. München, Germany: Oberbayern-Presse.

Zimdars-Swartz, S. L. (2014). Encountering Mary: From La Salette to Medjugorje. Princeton, NJ: Princeton University Press. 